\title{
Polityka przekształceń własnościowych przedsiębiorstw państwowych w przemyśle stoczniowym w Polsce po 1989 roku
}

\begin{abstract}
Streszczenie: Przekształcenia własnościowe przedsiębiorstw państwowych były jednym z elementów transformacji ustrojowej Polski, która rozpoczęła się pod koniec lat osiemdziesiątych XX wieku. Zmiany własnościowe objęły stocznie produkcyjne, które miały wpływ na poziom rozwoju gospodarczego państwa oraz były symbolem wydarzeń politycznych. Przebieg procesu przekształceń własnościowych stoczni był uzależniony od decyzji rządu. Nie bez znaczenia była też sytuacja na światowym rynku stoczniowym oraz przystapienie Polski do Unii Europejskiej. Z tego też powodu proces ten był przedmiotem szczególnej uwagi wśród polityków, badaczy oraz społeczeństwa, budząc spory i kontrowersje. Celem artykułu jest przeanalizowanie polityki poszczególnych rządów w zakresie przekształceń własnościowych przedsiębiorstw państwowych w przemyśle stoczniowym, ukazując czynniki które miały wpływ na przebieg procesu prywatyzacji stoczni. Przeprowadzając analizę polityki Rady Ministrów w zakresie przekształceń własnościowych stoczni produkcyjnych, dążono do uzyskania odpowiedzi na następujące pytania badawcze: Czy rząd polski wypracował spójną koncepcję przekształceń własnościowych przedsiębiorstw państwowych w przemyśle stoczniowym? Jakie decyzje podejmowały poszczególne rządy w celu prywatyzacji stoczni? oraz Jakie czynniki miały wpływ na proces zmian własnościowych stoczni? W badaniach wykorzystano metodę komparatystyczną, decyzyjną, instytucjonalno-prawną i statystyczną. Szczególną uwagę zwrócono na przebieg procesu prywatyzacji stoczni po wejściu Polski do Unii Europejskiej. Polityka prywatyzacyjna została zaprezentowana na przykładzie stoczni w Szczecinie, Gdańsku i Gdyni.
\end{abstract}

Słowa kluczowe: polityka przekształceń własnościowych, transformacja, rząd polski, przemysł stoczniowy, Unia Europejska

\section{Wprowadzenie}

O bowiązująca w Polsce Ludowej gospodarka centralnie planowana charakteryzowała się marnotrawstwem zasobów, czasu, niską innowacyjnością, wytwarzaniem nadwyżek ekonomicznych i wzrostem inflacji. Stan polskiej gospodarki, a wraz z nim pojawiające się kryzysy społeczne zmusiły kierownictwo partii komunistycznej (Polskiej Zjednoczonej Partii Robotniczej) do podjęcia reform gospodarczych, które miały miejsce w latach pięćdziesiątych, siedemdziesiątych i osiemdziesiątych XX wieku (Bałtowski, 2009, s. 255; Grala, 2005, s. 25). Próby zreformowania gospodarki nie zmieniły istoty obowiązującego systemu gospodarczego. Główną przyczyną był brak demokratycznego systemu politycznego. Niemniej jednak wysiłki podjęte w celu zreformowania gospodarki były jednym z czynników, które zapoczątkowały przejście z gospodarki centralnie planowanej do rynkowej. Zasadniczy wpływ na zmianę systemu ekonomicznego miała zmiana ustroju politycznego w Polsce, która nie byłaby możliwa bez gorbaczowskiej „pierestrojki” (Dudek, 2013, s. 17-19). 
Transformacja systemowa w Polsce zapoczątkowana pod koniec lat osiemdziesiątych XX wieku stworzyła możliwości zmiany sytemu ekonomicznego. Jednym z głównych kierunków transformacji sytemu gospodarczego były przekształcenia własnościowe przedsiębiorstw państwowych, a z wraz z nimi prywatyzacja tych podmiotów (Bałtowski, Miszewski, 2006, s. 221-223; Kieżun, 2012, s. 119; Berend, 2011, s.72). Dzięki zmianom własnościowym starano się zwiększyć efektywność funkcjonowania i konkurencyjność polskich przedsiębiorstw oraz dostosować ich działalność do zasad systemu gospodarki rynkowej.

Celem artykułu jest zaprezentowanie polityki rządu w zakresie przekształceń własnościowych przedsiębiorstw państwowych w przemyśle stoczniowym w Polsce w latach 1989-2010 na podstawie przeprowadzonej analizy dokumentów i decyzji Rady Ministrów (RM). Analizując politykę przekształceń własnościowych przedsiębiorstw państwowych ${ }^{1}$ w przemyśle stoczniowym poszczególnych rządów starano się odpowiedzieć na następujące pytania problemowe:

1. Czy rząd polski wypracował spójną koncepcję przekształceń własnościowych przedsiębiorstw państwowych w przemyśle stoczniowym?

2. Jakie decyzje podejmowały poszczególne rządy w celu prywatyzacji stoczni?

3. Jakie czynniki miały wpływ na proces zmian własnościowych stoczni?

Dążąc do uzyskania odpowiedzi na postawione pytania w badaniach wykorzystano metodę komparatystyczną, decyzyjną, instytucjonalno-prawną i statystyczną. Problematyka związana z polityką rządu w zakresie przekształceń własnościowych w przemyśle stoczniowym została przeanalizowana na przykładzie stoczni w Szczecinie, Gdańsku i Gdyni. Wartości kwotowe podane w artykule zostały w celu ich ujednolicenia przeliczone i podane po denominacji.

\section{Założenia polityki rządu w zakresie przekształceń własnościowych przedsiębiorstw państwowych w przemyśle stoczniowym}

Proces zmian własnościowych przedsiębiorstw państwowych zapoczątkował rząd Tadeusza Mazowieckiego, zgodnie z programem gospodarczym autorstwa ówczesnego ministra finansów Leszka Balcerowicza. Zanim rozpoczęto proces zmian własnościowych, wprowadzono $\mathrm{w}$ życie ustawę o prywatyzacji przedsiębiorstw państwowych (Ustawa z dnia 13 lipca 1990 r. o prywatyzacji...; Bałtowski, 2002, s. 147; Góralczyk, 2007, s. 60) i o utworzeniu urzędu Ministra Przekształceń Własnościowych (Ustawa z dnia 13 lipca 1990 r. o utworzeniu...). Minister przekształceń własnościowych (a od października 1996 roku minister Skarbu Państwa) był podstawowym organem wykonawczym określającym kierunki przekształceń własnościowych przedsiębiorstw państwowych, a następnie realizację programów gospodarczych.

Pierwszym rządem, który uznał, iż prywatyzację stoczni produkcyjnych należy przeprowadzić w pierwszych dwóch latach transformacji systemowej był rząd Jana Krzysztofa Bieleckiego. W rządowym Programie prywatyzacji sektorowej (Prywatyzacja sek-

${ }^{1}$ Polityka przekształceń własnościowych oznacza świadome działanie władzy państwowej zmierzającej do przekształcenia własności państwowej w prywatną. Prywatyzacja była jedną z form przekształceń własnościowych (Vademecum ..., 1991, s. 11). 
torowa..., 1991, s. 67), obejmującym ponad 500 przedsiębiorstw znalazły się stocznie produkcyjne takie jak Stocznia Gdańska SA², Stocznia Gdynia im. Komuny Paryskiej, Stocznia Szczecińska im. A. Warskiego. Prywatyzacja stoczni produkcyjnych w pierwszych latach funkcjonowania gospodarki rynkowej miała zapobiec niekorzystniej sytuacji finansowej, w jakiej znalazły się te przedsiębiorstwa. Proces przekształceń własnościowych stoczni miał polegać na prywatyzacji kapitałowej (Krajewski, 2009, s. 47). Planowana przez gabinet J. K. Bieleckiego prywatyzacja stoczni nie została uwzględniona w programach kolejnych rządów, aż do czasu powołania rządu Kazimierza Marcinkiewicza.

W programach Założenia polityki morskiej państwa do 2000 roku ${ }^{3}$ oraz Polityka przemystowa (Polityka przemystowa..., 1993, k. 39, 80; Kozarowicz, Skowrońska, 2005, s. 129) przyjętych przez rząd Hanny Suchockiej nie przewidziano prywatyzacji skomercjalizowanych stoczni. Z uwagi na nierentowność stoczni produkcyjnych oraz ich wysokie zadłużenie wobec budżetu państwa planowano przeprowadzić restrukturyzację organizacyjna, finansową i zatrudnienia tych przedsiębiorstw. Starano się stworzyć warunki do rozwoju przemysłu stoczniowego, między innymi w formie poręczeń gwarancji kredytów bankowych lub przedpłat armatorskich, wprowadzenie ulg inwestycyjnych dla polskich armatorów zamawiających statki w polskich stoczniach (Założenia polityki..., 1993, k. 284).

Podobnie jak gabinet H. Suchockiej, rządy Waldemara Pawlaka, Józefa Oleksego i Włodzimierza Cimoszewicza z uwagi na rosnące zadłużenie stoczni produkcyjnych planowały przeprowadzić ich restrukturyzację organizacyjną, finansową, majątkową i zatrudnienia oraz wprowadzić środki wspierające polskie stocznie na przykład w formie ulg lub dopłat do budowanych statków. Programy rządów Jerzego Buzka i Jana Olszewskiego, nie zawierały założeń polityki przekształceń własnościowych przedsiębiorstw państwowych w przemyśle stoczniowym.

Rządy Leszka Millera i Marka Belki podobnie jak gabinety H. Suchockiej, W. Pawlaka, J. Oleksego i W. Cimoszewicza nie przewidywały prywatyzacji stoczni produkcyjnych. Ze względu na pogłębiające się problemy finansowe stoczni uznano, że najlepszym rozwiązaniem będzie ich restrukturyzacja w obszarze zatrudnienia, obniżenia kosztów produkcji. Za przeprowadzenie restrukturyzacji w stoczni w Gdyni i Szczecinie RM zobowiązała zarządy przedsiębiorstw. Gabinet L. Millera przewidział udzielenie stoczniom pomocy finansowej, która miała być przeznaczona na restrukturyzację finansową i organizacyjną. Rząd M. Belki, oprócz restrukturyzacji stoczni, zapowiedział konsolidację sektora stoczniowego przez powołanie Korporacji Polskie Stocznie SA, w celu ograniczenia wydatków przedsiębiorstw, oraz uruchomienie dopłat do umów na budowę niektórych statków. Wynik wyborów parlamentarnych we wrześniu 2005 roku, a następ-

2 Stocznia Gdańska im. Lenina w odróżnieniu od Stoczni Gdyńskiej im. Komuny Paryskiej i Stoczni Szczecińskiej im. A. Warskiego decyzją rządu Mieczysława Rakowskiego w listopadzie 1988 r. została postawiona w stan likwidacji. Proces likwidacji stoczni został powstrzymany decyzją ministra przemysłu Tadeusza Syryjczyka. W kwietniu 1990 r. na bazie majątku Stoczni Gdańskiej im. Lenina w likwidacji utworzono spółkę o nazwie Stocznia Gdańska SA (Informacja o wynikach kontroli dziatalności..., 1997, s. 27, 83).

${ }^{3}$ Był to pierwszy dokument, który określił założenia polityki morskiej państwa (Założenia polity$k i \ldots$, 1993, k. 266; Patkowski, 2010, s. 132). 
nie powołanie rządu K. Marcinkiewicza spowodowało zaprzestanie działań rządu w zakresie realizacji programu konsolidacji sektora stoczniowego. Gabinet K. Marcinkiewicza rozpoczął prace nad opracowaniem strategii dla sektora stoczniowego ${ }^{4}$, które były kontynuowane przez gabinet Jarosława Kaczyńskiego. Dla gabinetu K. Marcinkiewicza i J. Kaczyńskiego celem strategii dla sektora stoczniowego było przeprowadzenie procesu prywatyzacji stoczni. Rządy te zapowiedziały pozyskanie inwestorów w celu przeprowadzenia procesu prywatyzacji stoczni. Przeprowadzenie jej było koniecznością nie tylko ze względu na realizację rządowego programu, ale i z powodu wymagań stawianych przez Komisję Europejską (KE). Plany te kontynuował gabinet Donalda Tuska.

Na podstawie przeanalizowanych rządowych programów z lat 1989-2010, należy stwierdzić, iż poszczególne ekipy rządowe niewiele uwagi poświęcały przyszłości stoczni produkcyjnych. Świadczy o tym fakt, iż tylko niektóre rządy opracowały programy ukazujące problematykę przekształceń własnościowych przedsiębiorstw państwowych w przemyśle stoczniowym. Porównując rządowe programy (jak również decyzje poszczególnych gabinetów) należy stwierdzić brak jednolitego stanowiska w zakresie polityki przekształceń własnościowych stoczni produkcyjnych kolejnych ekip rządowych. Ponadto założenia programowe miały charakter ogólnych tez, które były pozbawione kalendarium przeprowadzenia przekształceń własnościowych oraz sposobu pozyskana inwestorów zainteresowanych zakupem większościowego pakietu akcji stoczni. Poszczególne ekipy rządowe oprócz ogólnych założeń w zakresie polityki przekształceń własnościowych stoczni produkcyjnych nie wypracowały jednoznacznych mechanizmów służących poprawie konkurencyjności polskich stoczni na światowym rynku stoczniowym, co wpłynęło na pogłębienie się trudnej sytuacji ekonomicznej oraz przebieg procesu przekształceń własnościowych stoczni.

\section{Decyzje rządu w zakresie przekształceń własnościowych przedsiębiorstw państwowych w przemyśle stoczniowym}

Przebieg procesu przekształceń własnościowych stoczni był uzależniony od decyzji, jakie podejmowała RM. Nie bez znaczenia była też sytuacja na światowym rynku stoczniowym oraz przystapienie Polski do Unii Europejskiej (UE). Aby lepiej ukazać decyzje poszczególnych rządów, można wyróżnić trzy etapy polityki przekształceń własnościowych stoczni produkcyjnych.

Pierwszy z nich obejmuje lata 1990-2000. Początkowa cezura jest związana z rozpoczęciem procesu przekształceń własnościowych w polskiej gospodarce, rok 2000 symbolizuje zamknięcie etapu restrukturyzacji stoczni.

Drugi etap obejmuje okres od 2001 do 1 maja 2004 r. W roku 2001 doszło do kryzysu działalności polskich stoczni produkcyjnych. Końcowa cezura, czyli 1 maja 2004 roku, oznaczała przystapienie Polski do UE.

Trzeci etap rozpoczął się w maju 2004 roku. Obejmował on decyzje rządu w sprawie przeprowadzenia restrukturyzacji i prywatyzacji stoczni po wstapieniu Polski do UE. Rok 2010 to końcowa cezura, która wiąże się z zakończeniem sprzedaży majątku

${ }^{4}$ Dokument Strategia dla sektora stoczniowego (morskie stocznie produkcyjne) $w$ Polsce w latach 2006-2010 został przyjęty przez RM w sierpniu 2006 r. (Strategia dla..., 2006, s. 2-5). 
stoczni w Szczecinie i Gdyni. Decyzje rządu w zakresie przekształceń własnościowych przedsiębiorstw państwowych w przemyśle stoczniowym w Polsce w latach 1989-2010 zostały zaprezentowane $\mathrm{w}$ tabeli 1 .

Tabela 1

Decyzje rządu w zakresie przekształceń własnościowych przedsiębiorstw państwowych w przemyśle stoczniowym w Polsce w latach 1989-2010

\begin{tabular}{|c|c|c|}
\hline $\begin{array}{c}\text { Stocznia Szczecińska im. A. } \\
\text { Warskiego }\end{array}$ & $\begin{array}{l}\text { Stocznia im. Komuny Pary- } \\
\text { skiej w Gdyni }\end{array}$ & Stocznia Gdańska im. Lenina \\
\hline \multicolumn{3}{|c|}{ I ETAP 1990-2000 } \\
\hline \multicolumn{2}{|l|}{1991} & 1990 \\
\hline \multicolumn{2}{|c|}{ Przeksztalcenie przedsiębiorstw } & $\begin{array}{c}\text { Utworzenie na bazie majątku stocz- } \\
\text { ni w likwidacji: } \\
\text { j.s.SP Stoczni Gdańskiej SA }\end{array}$ \\
\hline 1992 & 1993 & 1994 \\
\hline \multicolumn{3}{|c|}{ Restrukturyzacja finansowa } \\
\hline $\begin{array}{l}\text { Postępowanie układowe między } \\
\text { wierzycielami a stocznią }\end{array}$ & \multicolumn{2}{|c|}{ Bankowe postępowanie ugodowe $\mathrm{z}$ wierzycielami stoczni } \\
\hline \multicolumn{3}{|c|}{ Restrukturyzacja organizacyjna, majątkowa i zatrudnienia } \\
\hline przeprowadzona & \multicolumn{2}{|c|}{\begin{tabular}{|c|} 
nieprzeprowadzona \\
\end{tabular}} \\
\hline 1993-1999 & 1996 & $1995-1996$ \\
\hline \multicolumn{2}{|c|}{$\begin{array}{l}\text { Restrukturyzacja organizacyjna } \\
\text { powstanie struktury holdingowej poprawa efektywności pracy, } \\
\text { modernizacja środków produkcji w ramach programu wzrostu kon- } \\
\text { kurencyjności stoczni }\end{array}$} & $\begin{array}{l}\text { Pomoc rządu dla stoczni } \\
\text { - udzielenie poręczeń spłaty kredytów } \\
\text { bankowych stoczni ze środków bu- } \\
\text { dżetu państwa, }\end{array}$ \\
\hline \multicolumn{2}{|c|}{ Prywatyzacja menadżerska } & - sfinansowanie materiałów przezna- \\
\hline \multirow[t]{2}{*}{$\begin{array}{l}9,65 \% \text { akcji stoczni - Skarb Pań- } \\
\text { stwa }\end{array}$} & $\begin{array}{l}\text { 39\% akcji stoczni - Skarb Pań- } \\
\text { stwa }\end{array}$ & $\begin{array}{c}\text { czonych na budowę statków } \\
\text { Podjęcie decyzji o upadłości stoczni }\end{array}$ \\
\hline & & 1998 \\
\hline $\begin{array}{l}\text { Zmiana nazwy } \\
\text { Stocznia Szczecińska Porta } \\
\text { Holding SA }\end{array}$ & \multicolumn{2}{|c|}{$\begin{array}{l}\text { Nabycie przez Stocznię Gdynia od syndyka masy upadłościowej Stocz- } \\
\text { ni Gdańskiej SA } \\
\text { Zmiana nazwy - Stocznia Gdańska - Grupa Stoczni Gdynia SA }\end{array}$} \\
\hline
\end{tabular}

\begin{tabular}{|c|c|}
\hline \multicolumn{2}{|c|}{ II ETAP 2001-1.05.2004 } \\
\hline Stocznia Szczecińska Porta Holding SA & Stocznia Gdańska - Grupa Stoczni Gdynia SA \\
\hline 2002 & 2001 \\
\hline \multicolumn{2}{|c|}{$\begin{array}{l}100 \% \text { akcji stoczni } 52 \% \text { akcji Stoczni Gdynia SA } \\
\text { Utworzenie Stoczni Szczecińskiej Nowa Sp. z o.o. }\end{array}$} \\
\hline \multicolumn{2}{|c|}{ Restrukturyzacja organizacyjna, finansowa } \\
\hline \multicolumn{2}{|c|}{ III ETAP 2004-2010 } \\
\hline \multirow[t]{5}{*}{ Stocznia Szczecińska Nowa Sp. z o.o. } & Stocznia Gdańska - Grupa Stoczni Gdynia SA \\
\hline & 2006 \\
\hline & Wydzielenie Stoczni Gdańskiej z Grupy Stoczni Gdynia SA \\
\hline & 2007 \\
\hline & $\begin{array}{l}\text { Prywatyzacja Stoczni Gdańskiej SA } \\
\text { Zmiana nazwy - Stocznia Gdańsk SA }\end{array}$ \\
\hline \multicolumn{2}{|c|}{ styczeń - wrzesień 2008} \\
\hline \multicolumn{2}{|c|}{$\begin{array}{l}\text { Podjęcie decyzji o prowadzeniu negocjacji w sprawie prywatyzacji } \\
\text { Stoczni Szczecińskiej Nowa Sp. z o.o. oraz Stoczni Gdynia SA }\end{array}$} \\
\hline
\end{tabular}




\begin{tabular}{|c||}
\hline maj 2004-sierpień 2008 \\
\hline Udzielenie pomocy publicznej $-3 \mathrm{mld}$ zł $2 \mathrm{mld}$ zł \\
\hline grudzień 2008 \\
\hline $\begin{array}{c}\text { Przyjęcie przez parlament rządowego projektu ustawy o postępowaniu kompensacyjnym w pod- } \\
\text { miotach o szczególnym znaczeniu dla polskiego przemysłu stoczniowego }\end{array}$ \\
\hline maj 2009-listopad 2010 \\
\hline Pozyskanie inwestorów i sprzedaż majątków stoczni \\
\hline
\end{tabular}

Źródło: Opracowanie własne na podstawie: Strategia dla..., 2006, s. 6; Informacja o wynikach kontroli funkcjonowania..., 1996, s. 31; Informacja o wynikach kontroli restrukturyzacji..., 2009, s. 36.

W pierwszym etapie rządowej polityki przekształceń własnościowych, w 1990 roku, podjęto decyzję o utworzeniu Stoczni Gdańskiej SA na bazie majątku Stoczni Gdańskiej im. Lenina w likwidacji (Akt notarialny..., 1990, k. 87). Rok później przekształcono Stocznię Szczecińską im. Adolfa Warskiego oraz Stocznię im. Komuny Paryskiej w Gdyni w jednoosobowe spółki Skarbu Państwa (Informacja o wynikach kontroli sprawowania..., 2000, s. 8; Gapiński, Macierewicz, 1989, s. 8). Komercjalizacja przedsiębiorstw państwowych była wstępnym etapem ich prywatyzacji. Zgodnie z ustawą z dnia 13 lipca 1990 roku o prywatyzacji przedsiębiorstw państwowych udostępnienie akcji skomercjalizowanych stoczni miało nastąpić w ciaggu dwóch lat od dnia wpisania spółek do rejestru handlowego (Ustawa z dnia 13 lipca 1990 r. o prywatyzacji...). Od samego początku funkcjonowania skomercjalizowanych stoczni było wiadomo, że w tak krótkim czasie stocznie te nie zostaną sprywatyzowane. Trudności z przeprowadzeniem prywatyzacji stoczni w ciagu dwóch lat wynikały między innymi z braku rządowej koncepcji i programu prywatyzacji stoczni oraz działań rządu w celu pozyskania inwestora.

Skomercjalizowanie stoczni nastapiło w sytuacji braku zamówień na polskie statki z byłego Związku Radzieckiego oraz podjęcia przez polski rząd decyzji o likwidacji dopłat wyrównawczych do eksportu. W pierwszych latach transformacji systemowej w Polsce gwałtowny wzrost zadłużenia stoczni produkcyjnych był spowodowany konsekwencjami wprowadzonych decyzji rządu w ramach gospodarki rynkowej. W stosunku do działających przedsiębiorstw państwowych w przemyśle stoczniowym zastosowano restrykcyjną politykę fiskalną i kredytową. Była ona związana między innymi z: wprowadzeniem podatku od ponadnormatywnych wypłat wynagrodzeń (powszechnie zwany popiwkiem), wysoko oprocentowanych kredytów bankowych oraz odprowadzaniem dywidend, która uniemożliwiała inwestowanie i zaostrzeniem zasad naliczania amortyzacji (Karpiński, Paradysz, Soroka, Żółtkowski, 2013, s. 72). Niska wydajność pracy, wzrost cen materiałów oraz duże koszty produkcji nie stwarzały perspektyw przetrwania stoczni. Wzrost zadłużenia przedsiębiorstw i brak zaangażowania polskiego rządu w ich działalność wymusiły na kierownictwie polskich stoczni podjęcie działań ratunkowych.

W październiku 1991 roku zarząd Stoczni Szczecińskiej SA (SS SA) opracował program restrukturyzacji przedsiębiorstwa, który zakładał między innymi przeprowadzenie postępowania układowego pomiędzy wierzycielami a stocznią. Program restrukturyzacji został przyjęty przez rząd J. K. Bieleckiego. Efektem negocjacji zarządu stoczni z jej wierzycielami przy uczestnictwie przedstawicieli rządu dotyczących spłaty długów stoczni było jej oddłużenie i znaczna poprawa finansowa. W dniu otwarcia postępowania układowego zadłużenie SS SA wyniosło $260 \mathrm{mln}$ zł. Procesem układowym objęto prawie $180 \mathrm{mln}$ zł. (Pismo sekretarza..., 1992, k. 39). W stoczni, oprócz restrukturyzacji 
finansowej, przeprowadzono restrukturyzację organizacyjną, majątkową i zredukowano zatrudnienie.

Przeprowadzona restrukturyzacja stoczni w Szczecinie spowodowała skrócenie cyklu budowy statków, zmniejszenie kosztów produkcji oraz wysokiej jakości wytwarzanych produktów. Ponadto pozyskano nowe rynki zbytu dla budowanych nowych statków. W wyniku tych procesów w 1993 roku SS SA uzyskała dodatni wynik z działalności. W 1993 roku dochód spółki ze sprzedaży usług wyniósł 450,9 mln zł, a zysk netto osiągnął $11,1 \mathrm{mln} \mathrm{zł}$.

Zaangażowanie rządu w proces przekształceń własnościowych Stoczni Gdynia SA i Stoczni Gdańskiej SA, podobnie jak w przypadku SS SA, było ograniczone.

Decyzje kierownictwa stoczni w Gdyni i Gdańsku dotyczące restrukturyzacji finansowej zapadły później niż w SS SA. Ministerstwo Przekształceń Własnościowych (MPW) zaakceptowało opracowane przez kierownictwo stoczni w Gdyni i w Gdańsku programy restrukturyzacji. W Stoczni Gdynia SA bankowym postępowaniem ugodowym objęto $475 \mathrm{mln}$ zł, z czego 50\% umorzono, a pozostała część zobowiązań została zamieniona na akcje stoczni (Mering, 1996, s. 27).

Przeprowadzony proces oddłużenia Stoczni Gdynia SA uchronił przedsiębiorstwo przed upadłością, ale nie wpłynął on na poprawę funkcjonowania spółki, tak jak to miało miejsce w SS SA. Jedną z przyczyn było przewlekłe prowadzenie bankowego postępowania ugodowego ${ }^{5}$. Ponadto restrukturyzacji finansowej spółki nie towarzyszyła restrukturyzacja organizacyjna, majątkowa i zatrudnienia. Stocznia Gdynia SA nadal ponosiła wysokie koszty produkcji oraz operacji finansowych związanych z budową statków. Ograniczone możliwości stoczni w zakresie zaciagania kredytów i gwarancji bankowych powodowały permanentny niedobór środków finansowych, niezbędnych do zachowania rytmicznej produkcji. Narastające straty z działalności Stoczni Gdynia SA pod koniec 1994 roku sięgały $15 \mathrm{mln}$ zł, a dwa lata później - ponad $100 \mathrm{mln}$ zł (Informacja o wynikach kontroli sprawowania..., 2000, s. 19).

Jeszcze gorzej niż w Stoczni Gdynia SA wyglądała sytuacja w Stoczni Gdańskiej SA. Do końca 1993 roku, pomimo pogarszającej się sytuacji finansowej stoczni, jej zarząd, nie podjął żadnych działań w celu przygotowania programu restrukturyzacji. W pierwszych latach działalności stoczni brak było decyzji rządu w sprawie prywatyzacji stoczni w Gdańsku (Sprawozdanie rady..., 1992, k. 24).

Wraz z wyborem nowego prezesa Stoczni Gdańskiej SA i nowej rady nadzorczej w 1994 roku przeprowadzono restrukturyzację finansową przedsiębiorstwa, umorzono 14 mln zł wierzytelności, jakie miała stocznia u dostawców. Nie zredukowano zobowiązań wobec banków, które wynosiły prawie 119 mln zł i budżetu państwa z tytułu zaległego podatku od ponadwymiarowych wynagrodzeń w wysokości około $24 \mathrm{mln}$ zł. Oddłużaniu stoczni w Gdańsku nie towarzyszyły działania dostosowujące jej strukturę organizacyjną, majątek i procesy technologiczne do warunków zapewniających opłacalną produkcję statków. Straty stoczni powiększały też błędne decyzje produkcyjne, które miały wpływ na ponoszenie kar umownych za nieterminowe wykonanie kontraktów.

Jedynie SS SA poprawa sytuacji ekonomiczno-finansowej w 1993 roku w porównaniu z latami wcześniejszymi pozwoliła zarządowi stoczni opracować program jej prywatyzacji.

${ }^{5}$ W Stoczni Gdynia SA bankowe postępowanie ugodowe prowadzono od września 1993 r. do września 1995 r. (Informacja o wynikach kontroli sprawowania..., 2000 r., s. 17). 
Program ten był przedmiotem negocjacji kierownictwa stoczni z przedstawicielami rządu i związków zawodowych (Kamola-Cieślik, 2013, s. 246-251). Uzgodniona przez strony koncepcja prywatyzacji stoczni została przyjęta przez rząd H. Suchockiej w 1993 roku, stosowną uchwałą ${ }^{6}$. Należy zauważyć, że decyzja rządu H. Suchockiej o prywatyzacji stoczni w Szczecinie nie była uwzględniona w założeniach programowych rządu. W roku 1996, czyli wcześniej niż przewidywała przyjęta przez RM uchwała został zakończony proces prywatyzacji SS SA. Struktura własności stoczni była inna niż planowano. Stocznia w Szczecinie nadal była przedsiębiorstwem z dużym udziałem Skarbu Państwa. Po zakończeniu prywatyzacji SS SA, jej struktura akcjonariatu ukształtowała się następująco: 19,7\% - pracownicy, 9\% - zarząd stoczni, 15\% - Grupa Przemysłowa Sp. z o.o., 30\% - banki (które były własnością Skarbu Państwa), 26,3\% - Skarb Państwa (Koćmiel, 2003, s. 29).

W kwietniu 1998 roku na podstawie ustawy z dnia 30 września 1996 roku o komercjalizacji i prywatyzacji przedsiębiorstw państwowych wydano byłym i aktualnym pracownikom stoczni 15\% akcji SS SA należących do Skarbu Państwa. Ponadto w wyniku „fuzji Banku Gdańskiego SA z BIG-iem oraz wejścia na Warszawską Giełdę Papierów Wartościowych PBR-u i Banku Handlowego w Warszawie Stocznia Szczecińska SA stała się firmą prywatną" (Chądzyński, Piskorz-Nałęcki, Sobecki, 1998, s. 180). W strukturze własnościowej SS SA Skarb Państwa miał 11,75\% akcji. W latach 1998-1999 dokonano kilku transakcji kupna-sprzedaży akcji stoczni. Grupa Przemysłowa Sp. z o.o. reprezentowana przez członków zarządu SS SA wykupiła akcje stoczni od banków (Koćmiel, 2003, s. 30). W wyniku przeprowadzonych transakcji w połowie maja 1999 roku Skarb Państwa miał niecałe $10 \%$ akcji stoczni, natomiast ponad połowa akcji została nabyta przez członków jej zarządu. W latach 1998-1999 przeprowadzono restrukturyzację organizacyjną stoczni, co spowodowało utworzenie struktury holdingowej przedsiębiorstwa i zmianę jego nazwy na Stocznia Szczecińska Porta Holding SA (SSPH SA).

W chwili, gdy rozpoczęło się zbywanie akcji SS SA w ramach realizacji programu prywatyzacji, działalność zarówno stoczni w Gdyni, jak i w Gdańsku przynosiła straty. Deficytowa działalność stoczni gdyńskiej i gdańskiej była spowodowana nieskutecznymi działaniami naprawczymi tych przedsiębiorstw.

W 1996 roku Ministerstwo Skarbu Państwa (MSP) przyjęło opracowany przez kierownictwo Stoczni Gdynia SA Program wzrostu konkurencyjności stoczni przez poprawe efektywności pracy i modernizację środków produkcji. W wyniku podjęcia działań związanych z realizacją programu w latach 1997-1998 skrócono cykle produkcji, zwiększono liczbę i tonaż oddawanych statków oraz obniżono koszty produkcji. Restrukturyzacja Stoczni Gdynia SA poprawiła zdolność finansową stoczni, która osiagnęła w 1997 roku zysk netto w wysokości 51,7 mln zł, a rok później 114,6 mln zł (Informacja o wynikach kontroli sprawowania..., 2000, s. 20).

Podobnie jak w przypadku SS SA, w strukturze właścicielskiej Stoczni Gdynia SA nastąiły zmiany. W 1998 roku Stoczniowy Fundusz Inwestycyjny SA (SFI SA) utworzony między innymi przez prezesa zarządu Janusza Szalandę nabył od banków Skarbu Państwa akcje stoczni. W wyniku przejęcia 39,13\% akcji Stoczni Gdynia SA przez SFI SA, a także po nieodpłatnym udostępnieniu pracownikom $11,96 \%$ akcji Skarb Państwa

${ }^{6}$ Uchwała nr 66/93 Rady Ministrów z 10 sierpnia 1993 r. nie została opublikowana (Uchwała nr 66/93..., k. 6; Tałasiewicz, Molewicz, 2003, s. 20). 
utracił większościowy pakiet akcji Stoczni Gdynia SA. Skarb Państwa zachował 34\% akcji Stoczni Gdynia SA, a 14,19\% posiadali inni akcjonariusze. Przejęcie przez SFI SA akcji Stoczni Gdynia SA spowodowało iż, prezes i wiceprezes zarządu oraz przewodniczący Rady Nadzorczej Stoczni Gdynia SA reprezentujący SFI SA przejęli uprawnienia właścicielskie i nadzorcze wobec stoczni gdyńskiej. Porównując proces przekształceń własnościowych SS SA i Stoczni Gdynia SA należy stwierdzić, iż obie spółki zostały poddane prywatyzacji menadżerskiej.

W połowie lat dziewięćdziesiątych spośród trzech omawianych stoczni w najtrudniejszej sytuacji finansowo-ekonomicznej znajdowała się Stocznia Gdańska SA. Restrukturyzacja finansowa stoczni w Gdańsku nie przyniosła zamierzonych celów, co zostało przedstawione w pierwszej części artykułu (Dryll, 1996, s. 52; Banki mówiq, 1997, s. 35).

W tej sytuacji rządy J. Oleksego i W. Cimoszewicza pod wpływem strajków stoczniowców oraz interwencji kierownictwa stoczni udzieliły poręczeń spłaty kredytów bankowych zaciągniętych przez stocznię ze środków budżetu państwa, a także sfinansowały zakup materiałów przeznaczonych na budowę statków (Sprawozdanie stenograficzne..., 1997 r., s. 135). Decyzje MSP nie sprzyjały więc likwidacji przyczyn zadłużenia, a miały charakter doraźny - były podyktowane chęcią zapobieżenia skutkom zaistniałej sytuacji. W 1996 roku w wyniku narastających strat z działalności Stoczni Gdańskiej SA, które wynosiły $230 \mathrm{mln}$ zł i przekroczyły o $26 \mathrm{mln}$ zł kapitał własny spółki minister przekształceń własnościowych Wiesław Kaczmarek ogłosił publicznie zaproszenie do negocjacji w celu nabycia akcji stoczni. W związku z brakiem inwestora strategicznego oraz sytuacją finansowo-ekonomiczną stoczni rząd W. Cimoszewicza podjął decyzję o ogłoszeniu upadłości Stoczni Gdańskiej SA. W sierpniu 1996 roku Sąd Rejonowy w Gdańsku ogłosił upadłość Stoczni Gdańskiej i wyznaczył syndyka masy upadłościowej.

W grudniu 1998 roku Stocznia Gdynia SA nabyła od syndyka większość akcji Stoczni Gdańskiej SA. Wraz z przejęciem udziałów gdańskiej stoczni nastapiła zmiana nazwy Stoczni Gdynia SA na Stocznia Gdańska - Grupa Stoczni Gdynia SA (SG GSG SA) (Kamola-Cieślik, 2013, s. 282-284). Od 1999 roku SG GSG SA została objęta programem restrukturyzacji, którego celem była poprawa efektywności produkcji, racjonalne wykorzystanie majątku i zmniejszenie poziomu kosztów stałych. Pod koniec lat dziewięćdziesiątych SSPH SA oraz SG GSG SA osiągnęły zysk z działalności.

Od roku 2001 - czyli w czasie drugiego etapu polityki przekształceń własnościowych przedsiębiorstw państwowych w przemyśle stoczniowym - działalność stoczni w Szczecinie i Gdyni przynosiła straty. Utrata płynności finansowej przez SSPH SA wynikała z kilku czynników. Jednym z nich były błędy w zarządzaniu spółką przez kierownictwo między innymi podpisano kontrakty na budowę specjalistycznych jednostek (chemikaliowców), których realizacja opóźniała się. Innym czynnikiem powodującym utratę płynności finansowej stoczni w Szczecinie był utrzymujący się wysoki poziom kursu złotego w stosunku do dolara amerykańskiego stosowanego powszechnie do rozliczeń kontraktów stoczniowych. Ponadto banki przestały udzielać kredytów na budowę statków bez poręczeń państwa ze względu, że większość akcji stoczni należała do prywatnych udziałowców oraz z obawy na rosnące zadłużenie stoczni. Również wpływ na złą sytuację finansową stoczni miały oferty tanich statków produkowanych w Chi- 
nach, Korei Południowej i w Indiach (Sejm Rzeczypospolitej Polskiej, kadencja IV, druk nr 2321..., 2003, s. 11).

Rosnące zadłużenie SSPH SA było podstawą podjęcia przez zarząd decyzji o ogłoszeniu upadłości spółki. W maju 2002 roku rząd L. Millera po rozmowach przeprowadzonych z zarządem stoczni przejął większość akcji stoczni za symboliczną złotówkę (Binek, Tałasiewicz, 2011, s. 78). Celem rządu było utrzymanie przemysłu stoczniowego, który warunkował rozwój regionu, a także powstrzymanie protestów społecznych i wzrostu bezrobocia.

Stoczniowy holding prywatny nie przetrwał próby czasu. W czerwcu 2002 roku stan zadłużenia SSPH SA wynosił około 2 mld zł, między innymi wobec banków, firm kooperujących ze stocznią, pracowników (Uzasadnienie do..., 2002, k. 91). W lipcu 2002 roku powołano podmiot o nazwie Stocznia Szczecińska Nowa Sp. z o.o. (SSN) jako firmę państwową.

W 2000 roku problemy finansowe dotknęly również SG GSG SA. Zawarte przez stocznię kontrakty na budowę statków, przynosiły straty, co wynikało z błędów w zarządzaniu stocznią (Biała księga..., 2008, s. 71-74). Podobnie jak w szczecińskiej stoczni doszło do zmian w strukturze własnościowej. W 2001 roku Skarb Państwa był właścicielem ponad połowy akcji Stoczni Gdynia SA.

Po przejęciu przez Skarb Państwa stoczni w Gdyni i Szczecinie rząd L. Millera podjął decyzję o przeprowadzeniu ich restrukturyzacji. W latach 2001-2004 rząd na mocy ustawy o pomocy publicznej (Ustawa z dnia 30 czerwca 2000 r. o warunkach...) wydał odpowiednie rozporządzenia (Rozporządzenie Rady Ministrów z dnia 20 lutego $2001 \mathrm{r}$. w sprawie...; Rozporządzenie Rady Ministrów z dnia 15 października 2002 r. w sprawie...) w celu udzielenia pomocy stoczniom $\mathrm{w}$ ramach realizacji programu restrukturyzacji. Pomoc publiczna była udzielona stoczniom w różnych formach między innymi pożyczek, dotacji, poręczeń spłat kredytów na budowę statków (Pomoc publiczna..., 2008, s. 4, 7). Bez interwencji państwa nie było możliwe wznowienie produkcji statków w Szczecinie oraz kontynuowanie działalności SG GSG SA. Pomoc publiczna udzielona w latach 2001-2004 Stoczni Gdynia SA wyniosła ponad 1 mld $200 \mathrm{mln}$ zł, Stoczni Gdańsk SA - 100 mln zł. Stocznia w Szczecinie otrzymała zaś w latach 2002-2004 pomoc w wysokości około 3 mld zł (Informacja o wynikach kontroli wykorzystania..., 2007, s. 10-12).

Udzielona stoczniom w Szczecinie (w latach 2002-2004), w Gdańsku oraz w Gdyni (w latach 2001-2004) pomoc publiczna oraz realizacja programu restrukturyzacji nie wpłynęły na poprawę sytuacji ekonomiczno-finansowej stoczni produkcyjnych. Niska wydajność pracy oraz kontrakty, których realizacja okazała się deficytowa, to główne przyczyny strat SSN w 2004 roku (odnotowano stratę na poziomie ponad $65 \mathrm{mln}$ zł) i SG GSG SA (wyniosły one ponad $1 \mathrm{mld}$ zł). W tym samym czasie RM nie podjęła żadnych działań z pozyskaniem inwestorów dla stoczni.

Trzeci etap polityki przekształceń własnościowych stoczni produkcyjnych rozpoczą się wraz z wejściem Polski do UE, a zakończył w chwili prywatyzacji stoczni w Gdańsku i sprzedaży majątku stoczni w Gdyni i Szczecinie.

Sprawujący przez ponad rok władzę rząd M. Belki w celu osiagnięcia rentowności stoczni opracował i przyjął program działań związany z konsolidacją sektora stoczniowego. Zmiana rządu oznaczała zaniechanie realizacji programu. Ponadto brak okresu 
przejściowego dla dostosowania polskiego przemysłu stoczniowego do wymagań prawa europejskiego ${ }^{7}$ spowodowało, iż od czerwca 2005 roku proces zmian własnościowych polskich stoczni stanowił przedmiot oceny KE. Było to wynikiem prowadzonego przez komisję postępowania dotyczącego zbadania zgodności udzielonej pomocy publicznej dla polskich stoczni z przepisami wspólnotowymi.

Rząd polski na polecenie KE opracował strategię dla sektora stoczniowego na lata 2006-2010, w którym przedstawiono działania dotyczące prywatyzacji stoczni produkcyjnych (Kamola-Cieślik, 2012, s. 247). Dla rządów K. Marcinkiewicza i J. Kaczyńskiego prywatyzacja była jedyną drogą zwiększenia konkurencyjności polskich stoczni na światowym rynku. W sierpniu 2006 roku zgodnie z przyjętą przez rząd J. Kaczyńskiego strategią dla sektora stoczniowego (Strategia dla..., 2006, s. 2), prywatyzację stoczni w Szczecinie i Gdyni planowano zakończyć do czerwca 2007 roku, natomiast stoczni w Gdańsku - rok później.

Zanim nastapiła prywatyzacja trzech stoczni w sierpniu 2006 roku rząd wydzielił z Grupy Stocznia Gdynia SA stocznię w Gdańsku (Klein, 2005, s. 9). W tym samym czasie nastapiła zmiana nazwy przedsiębiorstwa ze Stoczni Gdańskiej SA na Stocznię Gdańsk SA. Rządowe plany odnośnie stoczni w Gdańsku były popierane przez związki zawodowe stoczni gdańskiej, ze względu na brak kompetencji zarządzającej kadry SG GSG SA. W 2007 roku, w wyniku prowadzonych negocjacji, rząd polski sprzedał większość udziałów Stoczni Gdańskiej SA spółce ISD Polska Sp. z o.o. należącej do ukraińskiego właściciela z Donbasu. W 2007 roku ukraiński inwestor był właścicielem 83\% akcji Stoczni Gdańsk SA. Zobowiązania rządu J. Kaczyńskiego dotyczące prywatyzacji stoczni w Szczecinie i Gdyni nie zostały dotrzymane. Przyczyną było niewielkie zainteresowanie inwestorów zakupem udziałów w stoczniach.

Rząd D. Tuska kontynuował działania zmierzające do prywatyzacji stoczni w Szczecinie i Gdyni. Trwające kilka miesięcy negocjacje z inwestorami nie przyniosły jednak efektów (Sejm Rzeczypospolitej Polskiej, kadencja VI, druk nr 900..., 2008, s. 13). Głównym powodem była nierentowność spółek. Ponadto KE zakwestionowała plany restrukturyzacyjne przygotowane przez potencjalnych inwestorów ze względu na brak możliwości sfinansowania restrukturyzacji stoczni z własnych środków inwestorów zainteresowanych prywatyzacją spółek.

Ponadto w listopadzie 2008 roku KE uznała udzieloną od 2004 roku pomoc publiczną dla SSN i Stoczni Gdynia SA za niezgodną z prawem wspólnotowym ${ }^{8}$. W ocenie Komisji od 2004 roku stocznie nie osiagnęły zysku z produkcji żadnego statku, a swoją działalność zawdzięczały dotacjom. Wymusiło to sprzedaż majątku stoczni, a następnie likwidację przedsiębiorstw. Udzielona stoczniom pomoc publiczna musiała zostać zwrócona (Dryll, 2009, s. 20).

W celu realizacji wydanej przez KE decyzji w sprawie zgodności udzielenia polskim stoczniom pomocy publicznej z prawem unijnym, rząd przygotował projekt ustawy

${ }^{7}$ Rząd Leszka Millera nie włączył do pakietu negocjacyjnego związanego z traktatem akcesyjnym Polski do UE ustanowienia tzw. okresu przejściowego do dostosowania polskiego przemysłu stoczniowego do reguł wspólnego rynku (Dryll, 2008, s. 19).

${ }^{8}$ Od maja 2004 r. do sierpnia 2008 r. pomoc publiczna udzielona SS SA na restrukturyzację przedsiębiorstwa wyniosła 3 mld zł, Stoczni Gdynia SA -2 mld zł (Informacja o wynikach kontroli restrukturyzacji.., 2009, s. 39). 
o postępowaniu kompensacyjnym w podmiotach o szczególnym znaczeniu dla polskiego przemysłu stoczniowego (potocznie zwaną specustawą stoczniowa). Zanim projekt ustawy trafił do Sejmu RP był on przedmiotem konsultacji między stroną rządową a organizacjami związkowymi działającymi przy stoczniach. Strony ustaliły między innymi program ochrony pracowników, dobrowolnych odejść oraz zwolnień monitorowanych. Przyjęta przez Sejm RP ustawa o postępowaniu kompensacyjnym w podmiotach o szczególnym znaczeniu dla polskiego przemysłu stoczniowego (Ustawa z dnia 19 grudnia 2008 r. o postępowaniu...) określała między innymi zasady podziału, sprzedaży majątku stoczni w Szczecinie i Gdyni, powołania administracji odpowiedzialnej za likwidację stoczni.

W maju 2009 roku doszło do sprzedaży majątku stoczni. Większość przetargów wygrała nieznana spółka Stichting Particulier Fonds (SPFG) reprezentująca inwestora z Kataru (Kraśnicki, 2009a, s. 1; Gargas, 2009, s. 4). W sierpniu spółka wycofała się z zakupu stoczni w Szczecinie i Gdyni (Niklewicz, 2009, s. 31). W listopadzie 2009 roku odbył się drugi przetarg na aktywa SSN i Stoczni Gdynia SA, podczas którego nie udało się sprzedać wszystkich nieruchomości produkcyjnych (Kraśnicki, 2009b, s. 1). Dopiero w listopadzie 2010 roku Towarzystwo Finansowe „Silesia” Sp. z o.o. kupiło kluczowe nieruchomości SSN i wydzierżawiło je spółce „Kraftport” Sp. z o.o., która zobowiązała się do podjęcia działalności stoczniowej do 1 marca 2012 roku. Spółka „Kraftport” Sp. z o.o. pomimo zobowiązania nie podjęła działalności na terenie postoczniowym. W marcu 2014 roku Sąd Okręgowy w Szczecinie orzekł, że umowa podpisana pomiędzy Towarzystwem Finansowym „Silesia” Sp. z o.o. i spółką „Kraftport” Sp. z o.o. jest nieważna, ponieważ minister Skarbu Państwa nie wyraził na nią zgody (Kowalewska, 2012, s. 1). W sierpniu 2010 roku główne obszary produkcyjne majątku Stoczni Gdynia SA nabyły między innymi: Stocznia Crist SA, Stocznia Remontowa „Nauta” SA, Energomontaż Północ Sp. z o.o. i Gafako Sp. z o.o.

W październiku 2011 roku zakończono postępowanie kompensacyjne SSN a rok później Stoczni Gdynia SA. Było to możliwe po zaspokojeniu wierzytelności i realizacji programu ochrony praw pracowników środkami pochodzącymi ze sprzedaży majątku stoczni. W wyniku prowadzonych przetargów na sprzedaż składników majątkowych przedsiębiorstwa, SSN uzyskała $121 \mathrm{mln}$ zł, a Stocznia Gdynia SA uzyskała 421,5 mln zł. Po ogłoszeniu upadłości spółki nastąpiło przekazanie niesprzedanego majątku Stoczni Gdynia SA syndykowi, który po zinwentaryzowaniu i wycenie mienia stoczni, rozpoczął jego sprzedaż. Syndyk w odróżnieniu od zarządcy kompensacji miał prawo sprzedać zakład w całości, a nie w częściach, w formie pakietów (Kraśnicki, 2009c, s. 3) oraz przeprowadzić nieograniczoną liczbę przetargów, obniżając za każdym razem cenę wyjściową majątku przedsiębiorstwa.

\section{Podsumowanie}

Odpowiadając na pierwsze pytanie postawione na początku artykułu, należy stwierdzić, że poszczególne rządy nie wypracowały jednolitej koncepcji przekształceń własnościowych przedsiębiorstw państwowych w przemyśle stoczniowym. Rządowe dokumenty zawierały ogólne tezy na temat restrukturyzacji, która miała uzdrowić przed- 
siębiorstwa. W latach 1989-2005 nie powstał rządowy program, który określałby kierunki prywatyzacji stoczni produkcyjnych oraz sposoby jej realizacji. Wyjątkiem był program rządu J. K. Bieleckiego, z tym, że miał on charakter ogólnych tez, brakowało w nim szczegółowego planu prywatyzacji stoczni. Większość rządowych programów przewidywała restrukturyzację stoczni produkcyjnych, która była etapem poprzedzającym ich prywatyzację. Taka sytuacja miała miejsce za czasów rządu H. Suchockiej wobec SS SA. Pomimo, iż rządowy program nie zakładał prywatyzacji SS SA podjęto decyzję o sprzedaży większości jej udziałów. Dopiero po przystąpieniu Polski do UE rząd polski - na polecenie KE - opracował strategię dla sektora stoczniowego na lata 2006-2010. Od tego momentu można mówić, że zmiany własnościowe omawianych stoczni nabrały dynamiki.

Odpowiadając na drugie pytanie, należy podkreślić, iż w pierwszych latach transformacji systemowej Rada Ministrów, nie mając koncepcji polityki przekształceń własnościowych przedsiębiorstw państwowych $\mathrm{w}$ przemyśle stoczniowym, angażowała się w sprawy tych przedsiębiorstw w niewielkim stopniu. Cała odpowiedzialność za opracowanie i realizację programów restrukturyzacyjnych spoczywała na kierownictwu stoczni, które miało ograniczone wsparcie rządu.

Przeprowadzona analiza wyników finansowych stoczni na podstawie materiału archiwalnego wskazuje, że po 2001 roku wszystkie trzy stocznie produkcyjne były deficytowe. Największe straty odnotowywano w produkcji. Rada Ministrów, chcąc uniknąć strajków stoczniowców oraz wzrostu stopy bezrobocia, udzielała pomocy publicznej tym podmiotom, pomimo że zdawała sobie sprawę, że nie mają one szans na rozwój. Rząa polski do 2005 roku nie podejmował żadnych działań mających na celu pozyskanie inwestorów. W kolejnych latach starania ministra Skarbu Państwa o znalezienie inwestora, w celu prywatyzacji stoczni w Szczecinie i Gdańsku zakończyły się niepowodzeniem. Jedynie Stocznia Gdańska SA została sprywatyzowana w 2007 roku. Decyzja KE, a następnie przyjęta przez polski parlament specustawa położyła kres działalności nierentownych przedsiębiorstw państwowych.

Udzielając odpowiedzi na ostatnie pytanie, należy stwierdzić, że zasadniczy wpływ na przebieg procesu przekształceń własnościowych stoczni produkcyjnych (zwłaszcza pozyskanie inwestora) miała polityka rządu, co potwierdzają również odpowiedzi na pierwsze dwa pytania. Nie bez znaczenia była też deficytowa działalność stoczni. W pierwszych latach transformacji systemowej w Polsce wpływ na nią miał brak form wspomagania działań restrukturyzacyjnych. Inną przyczyną było błędne zarządzanie stoczniami, na przykład nie w pełni przeprowadzona restrukturyzacja, zawieranie kontraktów na budowę statków, które okazały się deficytowe. Sytuację pogarszało umacnianie się złotówki wobec dolara. Pojawienie się konkurencyjnych stoczni z Chin, Korei Południowej, Japonii zmniejszyło portfel zamówień polskich stoczni.

\section{Bibliografia}

Akt notarialny dotyczący utworzenia Stoczni Gdańskiej SA, 13 kwietnia 1990 r., Archiwum Państwowe w Gdańsku, Stocznia Gdańska SA, sygn. 10004.

Bałtowski M. (2002), Przeksztatcenia własnościowe przedsiębiorstw państwowych w Polsce, PWN, Warszawa. 
Bałtowski M. (2009), Gospodarka socjalistyczna w Polsce, PWN, Warszawa.

Bałtowski M., Miszewski M. (2006), Transformacja gospodarcza w Polsce, PWN, Warszawa.

Banki mówiq ,nie” Stoczni Gdańskiej... (1997), „Nowe Życie Gospodarcze”, nr 9.

Berend I. T. (2011), Od bloku sowieckiego do Unii Europejskiej. Transformacja ekonomiczna i społeczna Europy Środkowo-Wschodniej od 1973 roku, Wydawnictwo Uniwersytetu Jagiellońskiego, Kraków.

Biała księga prywatyzacji polskich stoczni, Ministerstwo Skarbu Państwa, Warszawa, wrzesień 2008.

Binek P., Tałasiewicz M. (2011), Stocznia Szczecińska. Upadek, Wydawnictwo Kurier-Press, Szczecin.

Chądzyński W., Piskorz-Nałęcki J. W., Sobecki W. (1998), Stocznia Szczecińska 1948-1998, Wydawnictwo Studio 69, Szczecin.

Dryll I. (1996), Co się dzieje w Stoczni Gdańskiej, „Nowe Życie Gospodarcze” nr 30.

Dryll I. (2008), Podzwonne dla stoczni?, „Nowe Życie Gospodarcze” nr 31.

Dryll I. (2009), Stocznie pod (unijny) młotek..., „Nowe Życie Gospodarcze” nr 1-2.

Dudek A. (2013), Historia polityczna Polski 1989-2012, Wydawnictwo Znak, Kraków.

Gapiński R., Macierewicz O. (1989), Stocznia Szczecińska im. A. Warskiego w latach 1948-1988. Ludzie, wydarzenia, liczby, Krajowa Agencja Wydawnicza, Szczecin.

Gargas A., Kulisy kompromitujacej transakcji, „Gazeta Polska”, 19.08.2009.

Góralczyk W. (2007), Przyczynek do dziejów ustawodawstwa prywatyzacyjnego w Polsce, Wydawnictwo WSPiZ, Warszawa.

Grala D. T. (2005), Reformy gospodarcze w PRL (1982-1989). Próba uratowania socjalizmu, Wydawnictwo TRIO, Warszawa.

Informacja o wynikach kontroli działalności organów państwowych oraz władz Stoczni Gdańskiej w okresie od $1988 r$. do upadtości spótki, Najwyższa Izba Kontroli, Departament Skarbu Państwa i Prywatyzacji, Warszawa, kwiecień 1997.

Informacja o wynikach kontroli funkcjonowania przedsiębiorstw przemystu okrętowego w warunkach gospodarki rynkowej, Najwyższa Izba Kontroli, Delegatura w Gdańsku, Gdańsk, maj 1996.

Informacja o wynikach kontroli restrukturyzacji i prywatyzacji sektora przemystu stoczniowego w latach 2005-2007, Najwyższa Izba Kontroli, Delegatura w Gdańsku, Gdańsk, czerwiec 2009.

Informacja o wynikach kontroli sprawowania przez Skarb Państwa nadzoru nad działalnościq Stoczni Gdynia SA, Najwyższa Izba Kontroli, Departament Skarbu Państwa i Prywatyzacji, Warszawa, styczeń 2000.

Informacja o wynikach kontroli wykorzystania środków publicznych w sektorze stoczniowym w latach 2001-2005, Najwyższa Izba Kontroli, Delegatura w Gdańsku, Gdańsk, marzec 2007.

Kamola-Cieślik M. (2012), Proces prywatyzacji Stoczni Szczecińskiej Nowa Sp. z o.o. w latach 2004-2009, „Przegląd Politologiczny” nr 4.

Kamola-Cieślik M. (2013), Polityka przeksztatceń własnościowych przedsiębiorstw państwowych gospodarki morskiej w okresie transformacji systemowej w Polsce, Wydawnictwo ZAPOL, Szczecin.

Karpiński A., Paradysz S., Soroka P., Żółtkowski W. (2013), Jak powstawały i jak upadały zakłady przemystowe w Polsce, MUZA SA, Warszawa.

Kieżun W. (2012), Patologia transformacji, Wydawnictwo Poltext, Warszawa.

Klein J. (2005), ,Nie” dla zarzqdu, „Dziennik Bałtycki”, 29.08.

Koćmiel M. (2003), Rzeczpospolita Stoczniowa - spisek czy niekompetencja?, Wydawnictwo VLV, Szczecin.

Kowalewska J. (2012), Stocznia ma pecha. Umowa z Kraftportem nieważna, „Gazeta Wyborcza. Szczecin", 11.01. 
Kozarowicz H., Skowrońska A. (2005), Polityka przemysłowa, Wydawnictwo Akademii Ekonomicznej im. Oskara Langego we Wrocławiu, Wrocław.

Krajewski S. (2009), Prywatyzacja. Restrukturyzacja. Konkurencyjność polskich przedsiębiorstw, Polskie Wydawnictwo Ekonomiczne, Warszawa.

Kraśnicki A. (2009a), Będziemy robić statki, „Gazeta Wyborcza. Szczecin”, 18.05.

Kraśnicki A. (2009b), Stocznia niesprzedana, „Gazeta Wyborcza. Szczecin”, 29.11.

Kraśnicki A. (2009c), Stocznia - teraz syndyk, „Gazeta Wyborcza. Szczecin”, 15.09.

Mering K. (1996), Stocznie pod lupq, „Nowe Życie Gospodarcze” nr 29.

Niklewicz K. (2009), Stocznie skazane na Katar?, „Gazeta Wyborcza”, 2.09.

Patkowski K. (2010), Proces prywatyzacji w państwach Grupy Wyszehradzkiej. Aspekt polityczny i ideologiczny, Wydawnictwo Naukowe WSHiD, Poznań.

Pismo sekretarza stanu Ministerstwa Przekształceń Własnościowych Tomasza Stankiewicza do prezesa zarządu Stoczni Szczecińskiej SA Krzysztofa Piotrowskiego w sprawie postępowania układowego, Warszawa, maj 1992 r. Archiwum Państwowe w Szczecinie, Stocznia Szczecińska Spółka Akcyjna, sygn. 807.

Polityka przemysłowa, Warszawa, wrzesień 1993 r. Archiwum Akt Nowych w Warszawie, Ministerstwo Przemysłu i Handlu, sygn. 5/10.

Pomoc publiczna dla stoczni, Urząd Ochrony Konkurencji i Konsumentów, Warszawa, wrzesień 2008.

Prywatyzacja sektorowa. Materiat opracowany przez Ministerstwo Przeksztatceń Własnościowych (1991), „Przegląd Rządowy” nr 2.

Rozporządzenie Rady Ministrów z dnia 15 października 2002 r. w sprawie dopuszczalności pomocy publicznej w sektorze budownictwa okrętowego, Dz. U. 2002, Nr 186, poz. 1547.

Rozporządzenie Rady Ministrów z dnia 20 lutego 2001 r. w sprawie udzielenia pomocy publicznej w sektorze budownictwa okrętowego, Dz. U. 2001, Nr 28, poz. 304.

Sejm Rzeczypospolitej Polskiej, kadencja IV, druk nr 2321: Informacja rzqdu RP o stanie gospodarki morskiej, Warszawa, 18 listopada 2003.

Sejm Rzeczypospolitej Polskiej, kadencja VI, druk nr 900: Informacja na temat sytuacji w morskich stoczniach produkcyjnych Stocznia Szczecińska Nowa Sp. z o.o. i Stocznia Gdynia SA, Warszawa, 2 września 2008.

Sprawozdanie rady nadzorczej Stoczni Gdańskiej SA za 1992 r. Archiwum Państwowe w Gdańsku, Stocznia Gdańska SA, sygn. 10111.

Sprawozdanie stenograficzne z II kadencji Sejmu Rzeczypospolitej Polskiej: 103 posiedzenie z 20 marca 1997.

Strategia dla sektora stoczniowego (morskie stocznie produkcyjne) w Polsce w latach 2006-2010, Ministerstwo Gospodarki, Warszawa sierpien 2006.

Tałasiewicz M., Molewicz M. (2003), Szkic do analizy upadku Stoczni Szczecińskiej Porta Holding SA oraz jej grupy kapitatowej, w: Holding po polsku. Od sukcesów do porażek. Studia przypadków, red. A. Zelek, Wydawnictwo ZSB, Szczecin.

Uchwała nr 66/93 Rady Ministrów z dnia 10 sierpnia 1993 r. w sprawie trybu zbycia akcji Stoczni Szczecińskiej Spółki Akcyjnej, Archiwum Zakładowe Ministerstwa Skarbu Państwa w Warszawie, Ministerstwo Skarbu Państwa sygn. 719/1.

Ustawa z dnia 13 lipca 1990 r. o prywatyzacji przedsiębiorstw państwowych, Dz. U. 1990, Nr 51, poz. 298.

Ustawa z dnia 13 lipca 1990 r. o utworzeniu urzędu Ministra Przekształceń Własnościowych, Dz. U. 1990, Nr 51, poz. 299.

Ustawa z dnia 19 grudnia 2008 r. o postępowaniu kompensacyjnym w podmiotach o szczególnym znaczeniu dla polskiego przemystu stoczniowego, Dz. U. 2008, Nr 233, poz. 1569. 
Ustawa z dnia 30 czerwca 2000 r. o warunkach dopuszczalności i nadzorowania pomocy publicznej dla przedsiębiorców, Dz. U. 2000, Nr 60, poz. 704.

Uzasadnienie do wniosku o ogłoszenie upadłości Stoczni Szczecińskiej Porta Holding SA, Szczecin, 12 lipca 2002 r., Archiwum Zakładowe Ministerstwa Skarbu Państwa w Warszawie, Ministerstwo Skarbu Państwa, sygn. 3536/30.

Vademecum prywatyzacji (1991), Polskie Wydawnictwo Ekonomiczne, Warszawa.

Założenia polityki morskiej państwa do 2000 roku, Warszawa, 31 maj 1993 r., Archiwum Akt Nowych w Warszawie, Ministerstwo Transportu i Gospodarki Morskiej, sygn. 1/20.

\title{
The policy of ownership changes in state-owned companies in the shipbuilding industry in Poland after 1989
}

\begin{abstract}
Summary
Ownership changes in state-owned companies were part of the political transformation that started in Poland in the late 1980s. Ownership changes affected the production shipyards, which influenced Poland's economic development and earlier had been symbols of political importance. The ownership changes taking place in the Polish shipyards depended on the decisions made by Polish governments, but also on the situation on the global shipbuilding market and the fact that later Poland was to join the EU. Therefore, the changes attracted the attention of many politicians, academics and Polish society, arousing emotions, disputes and controversy. The aim of this paper is to analyze the policies of successive governments in terms of ownership changes in the shipbuilding sector. Attention is focused on the factors that affected the privatization of the Polish shipyards. While analyzing the policies of Polish cabinets concerning the ownership changes in the shipyards, we wanted to find the answers to the following questions: did the Polish government work out a coherent concept for changing the ownership structure in the shipbuilding industry? What decisions were made by successive Polish governments in order to reprivatize the shipyards? The study used comparative, decision-based, institutional, legal and statistical methods. Particular attention is paid to the process of reprivatization of the shipyards after Poland joined the EU. The examples of reprivatization in the shipyards of Szczecin, Gdańsk and Gdynia are given.
\end{abstract}

Key words: policy of ownership changes, transformation, Polish government, shipbuilding industry, $\mathrm{EU}$ 